ISSN: 2302-8556

E-Jurnal Akuntansi Universitas Udayana

Vol.27.1.April (2019): 764-791

DOI: https://doi.org/10.24843/EJA.2019.v27.i01.p28

\title{
Kinerja Keuangan Memediasi Pengaruh Corporate Social Responsibility dan Struktur Modal Terhadap Nilai Perusahaan
}

\author{
Sutriningsih ${ }^{1}$ \\ Lilik Handajani ${ }^{2}$ \\ Ahmad Rifa'i ${ }^{3}$ \\ ${ }^{1,2,3}$ Fakultas Ekonomi dan Bisnis Universitas Mataram (Unram), NTB, Indonesia \\ e-mail: sutriningsih926@yahoo.com
}

\begin{abstract}
ABSTRAK
Penelitian bertujuan menguji pengaruh corporate social responsibility dan struktur modal terhadap nilai perusahaan dengan kinerja keuangan sebagai variabel intervening. Populasi penelitian adalah perusahaan manufaktur yang terdaftar di BEI tahun 2015-2017 dan mengungkapkan corporate social responsibility. Sampel ditentukan denganpurposive sampling dandiperoleh 114 sampel. Alat analisis data menggunakan analisis jalur. Temuan penelitian menunjukkan bahwa kinerja keuangan (ROE) tidak dapat berfungsi sebagai variabel intervening dalam pengaruh CSR terhadap nilai perusahaan pada perusahaan manufaktur di BEI periode 2015-2017. Sedangkan pada struktur modal kinerja keuangan yang diproksikan dengan ROE dalam penelitian ini dapat berfungsi sebagai variabel intervening. Implikasi penelitian ini dapat berguna sebagai pertimbangan bagi perusahaan dalam membuat kebijakan terkait pengungkapan corporate social responsibility.
\end{abstract}

Kata Kunci :Corporate social responsibility, struktur modal, kinerja keuangan, nilai perusahaan.

\section{ABSTRACK}

The study aims to examine the effect of corporate social responsibility and capital structure on firm value with financial performance as an intervening variable. The research population is a manufacturing company listed on the Indonesia Stock Exchange in 2015-2017 and discloses corporate social responsibility. The sample was determined by purposive sampling obtained 114 samples. The data analysis tool uses path analysis. The findings of the study indicate that financial performance (ROE) cannot function as an intervening variable in the effect of CSR on the value of the company in the BEI manufacturing company in the period 2015-2017. Whereas the capital structure of financial performance that is proxied by ROE in this study can function as an intervening variable. The implications of this research can be useful as a consideration for companies in making policies related to disclosure of corporate social responsibility.

Keywords: Corporate social responsibility, capital structure, financial performance, company value.

\section{PENDAHULUAN}

Corporate social responsibility merupakan bentuk tanggung jawabperusahaan dalam memperbaiki kesenjangan socialdan kerusakan lingkungan yang terjadi akibat aktivitas operasional perusahaan. Semakin banyak bentuk pertanggungjawaban yang dilakukan perusahaan terhadap lingkungannya, image perusahaan menjadi meningkat. Investor lebih berminat padaperusahaan yang 
memiliki citra yang baik dimasyarakat karena semakin baiknya citra perusahaan, loyalitas konsumen semakin tinggi sehingga dalam waktu lama penjualan perusahaan akan membaik dan profitabilitas perusahaan juga meningkat. Jika perusahaan berjalan lancar, makanilai saham perusahaan akan meningkat (Retno \& Priantinah, 2012).

Struktur modal adalah proporsi pendanaan dengan hutang (debt financing) perusahaan, yaitu rasio laverage (pengungkit) perusahaan. Dengan demikian, hutang merupakan bagian dari struktur modal yang merupakan complex capital structure karena perusahaan tidak hanya menggunakan modal sendiri tetapi juga menggunakan modal pinjaman dalam struktur modalnya (Fahmi, 2016). Struktur modal merupakan kunci perbaikan produktivitas dan kinerja perusahaan (Kusumajaya, 2011 dalam Nadillah, 2017). Teori struktur modal menjelaskan bahwa kebijakan pendanaan perusahaan dalam menentukan struktur modal bertujuan untuk mengoptimalkan nilai perusahaan.

Nilai perusahaa nmerupakan gambaran menyeluruh dari suatu perusahaan. Nilai perusahaan akan diukur menggunakan rasio tobin's $q$. Tobin's adalah salah satu rasio yang dinilai bisa memberikan informasi paling baik, karena rasio ini bisa menjelaskan berbagai fenomena dalam kegiatan perusahaan.

Fakhruddin dan Hadianto (2001) dalam Moniaga (2013) menyebutkan bahwa nilai perusahaan merupakan persepsi investor terhadap perusahaan, yang sering dikaitkan dengan harga saham. Harga saham yang tinggi membuat nilai perusahaan juga tinggi. Harga saham merupakan harga yang terjadi pada saat saham di perdagangkan di pasar modal. 
Kinerja keuangan digunakan untuk memediasidalam penelitian ini karena prestasiyang ditunjukkan perusahaan dalam pencapaian tujuan perusahaan khususnya yangtercermin dari kondisi keuangan perusahaan. Informasiutama yang dapatmenggambarkan kinerja keuangan melalui laporan keuangan adalah laba atauprofitabilitas. Apabila perolehan laba dari tahun ke tahun mengalami kenaikan, akanmempengaruhi pembagian devidenserta keyakinan investor akan kelangsunganhidup perusahaan yangmelakukan CSR. Hal ini menarik bagi investor yang akan menanamkan modalnya pada suatu perusahaan.

Berdasarkan argumentasi di atas, maka peneliti merumuskan masalah sebagai berikut: 1. Apakah pengungkapan corporate social responsibility berpengaruh terhadap nilai perusahaan? 2. Apakah struktur modal berpengaruh terhadap nilai perusahaan ? 3 . Apakah pengungkapan corporate social responsibility berpengaruh terhadap kinerja keuangan? 4. Apakah struktur modal berpengaruh terhadap kinerja keuangan ? 5. Apakah kinerja keuangan berpegaruh terhadap nilai perusahaan? 6. Apakah pengungkapan corporate social responsibility berpengaruh terhadap nilai perusahaan dengan kinerja keuangan sebagai variabel intervening? 7. Apakah struktur modal berpengaruh terhadap nilai perusahaan dengan kinerja keuangan sebagai variabel intervening?

Adapun Grand Theory yang mendasari penelitian ini adalahteori keagenan (Agency Theory). Agency theory merupakan teori yang digunakan untuk menjelaskan hubungan antara pihak agen (yang menerima wewenang) dan prinsipal (pihak yang memberi wewenang) yang dibangun agar tujuan perusahaan dapat tercapai dengan maksimal. Inti dari hubungan keagenan adalah adanya pemisahan antara kepemilikan (principal/investor atau stockholders) dan pengendalian (agent/manajer). Kepemilikan diwakili oleh investor yang 
mendelegasikan kewenangan kepada agen dalam hal ini manajer untuk mengelola kekayaan investor. Investor mempunyai harapan bahwa dengan mendelegasikan wewenang pengelolaan tersebut, mereka akan memperoleh keuntungan dengan bertambahnya kekayaan dan kemakmuran investor. Prinsip utama dari teori ini menyatakan adanya hubungan kerja antara pihak yang memberi wewenang yaitu investor dengan pihak yang menerima wewenang yaitu manajer dan ini berarti hubungan keagenan adalah suatu kontrak dimana salah satu atau lebih orang (principal) melibatkan orang lain (agen) untuk melakukan beberapa layanan atas nama mereka yang melibatkan sebagian kewenangan pengambilan keputusan kepada agen (Jensen \& Meckling, 1976). Kinerja keuangan digunakan sebagai variabel intervening dalam penelitian ini, secara umum dapat menggambarkan tingkat pencapaian tujuan perusahaan. Salah satu media perusahaan untuk memberikan informasi mengenai kinerja keuangan adalah dengan mencantumkan ROE di dalam laporan keuangan. Semakin besar ROE mencerminkan kemampuan perusahaan dalammenghasilkan keuntungan yang tinggi bagi pemegang saham. Dalam agency theory menjelaskan hubungan antara pihak agen (yang menerima wewenang) dan prinsipal (pihak yang memberi wewenang) yang dibangun agar tujuan perusahaan dapat tercapai dengan maksimal. Sesuai dengan fokus yang digunakan untuk kinerja keuangan dalam penelitian ini yaitu ROE dimana ROE lebih mengarah pada kepentingan prinsipal (Stockholders) yang mengharuskan pihak perusahaan sebagai agen untuk menghasilkan laba dari investasi stockholders. 
Secara sistematis rerangka konseptual penelitian ini dapat dilihat pada gambar 1 sebagai berikut:

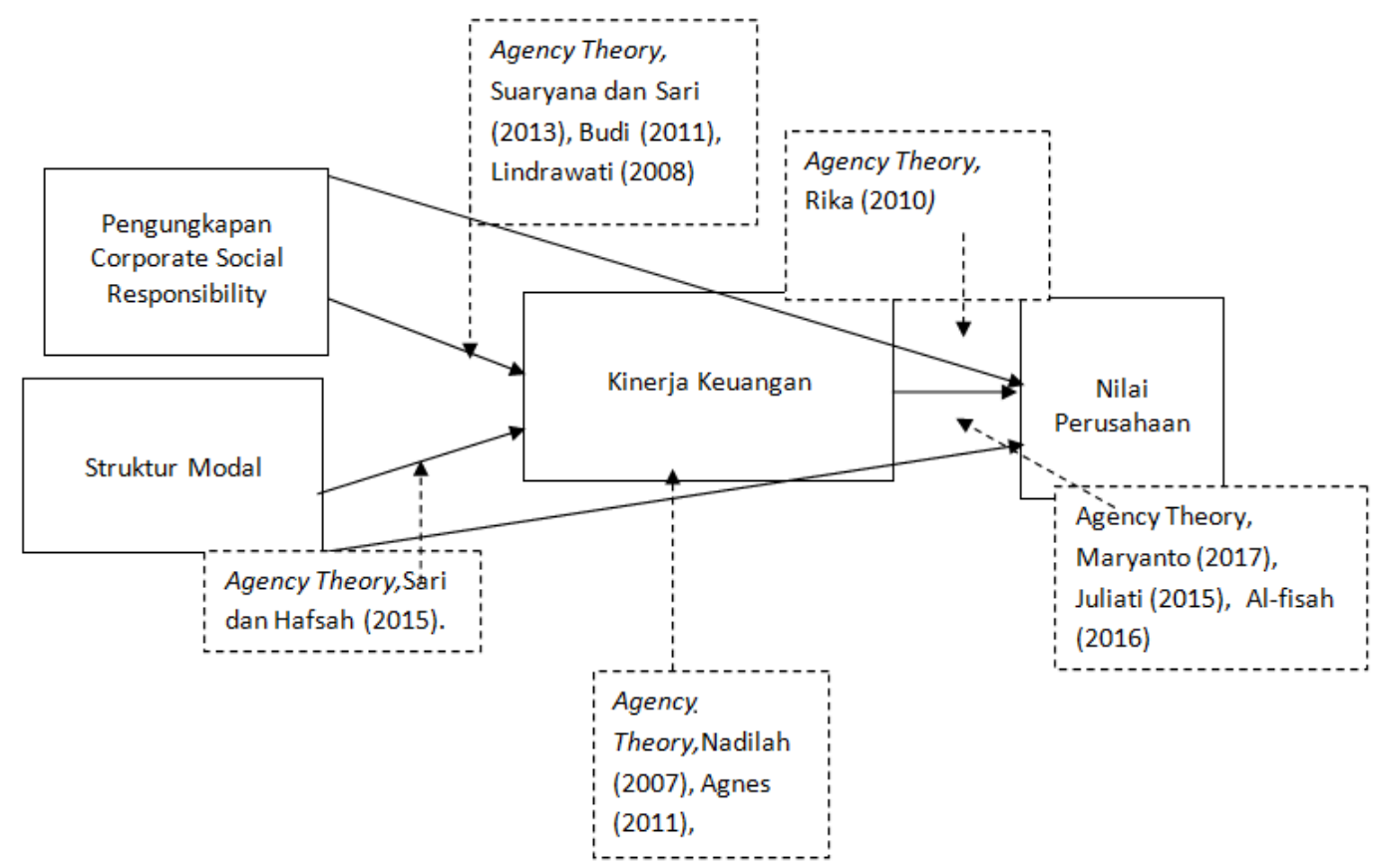

Sumber : Data diolah, 2019

\section{Gambar 1. Model Penelitian}

Berdasarkan agency theory (Jensen \& Meckling, 1976) yang menjelaskan hubungan kontraktual antara principal dan agent memiliki tujuan untuk meningkatkan kemampuan individu (baik principal maupun agent) dalam mengevaluasi lingkungan dimana keputusan harus di ambil (The belief revision role). Keputusan yang tepat terkait dengan evaluasi lingkungan akan mempengaruhi nilai perusahaan terutama pada perusahaan manufaktur karena berkaitan erat dengan lingkungan. Penelitian ini sebelumnya di lakukan (Ramadhani, Purnamawati, \& Sujana, 2017) yang menemukan bahwa CSR berpengaruh positif dan signifikan terhadap nilai perusahaan pada perusahaan manufaktur yang terdaftar di Bursa Efek Indonesia (BEI) periode 2013-2015. Hal ini menunjukkan memang benar ada pengaruh yang positif dan signifikan secara parsial 
antara CSR terhadap nilai perusahaan pada perusahaan manufaktur yang terdaftar di Bursa Efek Indonesia periode 2013-2015. Hasil penelitian menunjukkan bahwa semakin banyak pengungkapan CSR maka semakin tinggi pula nilai perusahaan. Apabila perusahaan memiliki kinerja lingkungan dan sosial yang baik, maka akan direspon positif oleh investor melalui peningkatan harga saham.

$\mathrm{H}_{1}$ : Pengungkapan CSR berpengaruh positif terhadap nilai perusahaan.

Menurut agency teory (Jensen \& Meckling, 1976) seorang manager atau agent memiliki tugas untuk mencari sumber-sumber dana yang bisa dipakai atau dimanfaatkan untuk dijadikan modal perusahaan. Secara umum modal perusahaan bersumber dari modal asing dan modal sendiri. Semakin tinggi struktur modal yang dimiliki oleh perusahaan secara otomatis akan dapat meningkatkan nilai perusahaan tersebut.Nadillah (2017)Menunjukkan bahwa struktur modal berpengaruh positif dan signifikan terhadap nilai perusahaan. Berdasarkan hasil penelitian, ketika struktur modal perusahaan semakin membaik, dengan membaiknya struktur modal maka akan meningkatkan nilai perusahaan. Hasil penelitian yang dilakukan oleh Pratheepkanth(2011)yang menunjukkan adanya pengaruh struktur modal terhadap ROA.

$\mathrm{H}_{2}$ : Struktur modal berpengaruh positif terhadap nilai perusahaan.

Saat ini pengungkapan CSR sebagai bentuk pertanggungjawaban sosial perusahaan merupakan suatu keharusan, jika dikaitkan dengan agency theory, tanggung jawab sosial dari perusahaan terjadi antara sebuah perusahaan dengan stockholders. CSR sebagai sebuah gagasan salah satunya dihadapkan pada tanggung jawab yang berpijak pada nilai perusahaan yang direfleksikan dalam 
kondisi keuangannya yang akan menunjukkan kinerja keuangan perusahaan tersebut.

Menurut Yuanita dan Gunawan (2017) semakin meningkatnya pengungkapan CSR yang diungkapkan, semakin besar pula tingkat pengembalian atas ekuitas. Pengungkapan CSR yang semakin luas akan memberikan sinyal positif kepada stakeholder dan shareholder yang akan menimbulkan kepercayaan pihak-pihak tersebut untuk menerima produk perusahaan sehingga meningkatkan laba dan ROE perusahaan.Hasil penelitian empiris mengenai pengaruh pengungkapan CSR terhadap kinerja keuangan dapat ditunjukkan oleh penelitian Sari \& Suaryana (2013)yang menemukan bahwa pengungkapan CSR berpengaruh positif dan signifikan terhadap kinerja keuangan.Ini berarti semakin tinggi pengungkapan CSR, semakin tinggi kinerja keuangan perusahaan.Ini berarti semakin tinggi pengungkapan CSR, semakin tinggi kinerja keuangan perusahaan.

$\mathrm{H}_{3}$ : Pengungkapan Corporate Social Responsibility berpengaruh positif terhadap terhadap kinerja keuangan.

Perusahaan dengan struktur modal optimal adalah perusahaan yang mempunyai hutang yang lebih kecil dibandingkan dengan modal sendiri, hal ini dikarenakan untuk menghindari adanya risiko yang lebih tinggi jika terjadi kebangkrutan. Struktur modal terdiri dari utang jangka panjang dan modal sendiri. Kaitannya dengan agency theory, bahwa pihak manajemen yang diberikan wewenang untuk mengelola perusahaan oleh stockholders, akan menghasilkan laba yang sesuai dengan harapan stockholders sebagai penyedia modal perusahaan, karena pada dasarnya semakin tinggi ROE (kinerja keuangan) maka 
semakin bagus karena hal tersebut mengindikasikan bahwa manajemen perusahaan mampu membuat perusahaan seefisien mungkin.

Perusahaan dengan struktur modal optimal adalah perusahaan yang mempunyai hutang yang lebih kecil dibandingkan dengan modal sendiri, hal ini dikarenakan untuk menghindari adanya risiko yang lebih tinggi jika terjadi kebangkrutan.Hasil penelitian yang dilakukan oleh Hafsah \& Sari (2015)enemukan bahwa Struktur Modal yang diukurdengan debt to total asset ratio dan variabel dependen adalah kinerja keuangan yangdiukur dengan economic value added (EVA), bahwa DARberpengaruh signifikan terhadap EVA. $\mathrm{H}_{4}$ : Struktur modal berpengaruh positif terhadap kinerja keuangan

Menurut agency theory (Jensen \& Meckling, 1976) menyebutkan bahwa agent atau manager sebagai perwakilan management diharapakan mampu memiliki kemampuan untuk memilih tujuan yang tepat atau suatu alat yang tepat untuk mencapai tujuan yang telah ditetapkan untuk mengurangi biaya yang telah ditetapkan. Efisiensi diartikan sebagai ratio (perbandingan) antara masukan dan keluaran yaitu dengan masukan tertentu memperoleh keluaran yang optimal.Ada kalanya kinerja keuangan mengalami penuruan. Untuk memperbaiki hal tersebut, salah satu caranya adalah mengukur kinerja keuangan dengan menganalisa laporan keuangan menggunakan rasio-rasio keuangan.Kinerja keuangan berpengaruh terhadap nilai perusahaan(Maryanto, 2017)karena kinerja keuangan akan menunjukkan kemampuan perusahaan untuk menghasilkan laba yang juga akan mempengaruhi nilai perusahaan. Stockholders sebagai principal akan 
memfokuskan perhatian pada laba yang dihasilkan oleh perusahaan mengingat stockholders sebagai owners equity.

$\mathrm{H}_{5}$ : Kinerja keuangan berpengaruh positif terhadap nilai perusahaan.

Selain memaksimalkan laba, tujuan perusahaan adalah meningkatkan nilai perusahaan. Kegiatan CSR dapat meningkatkan nilai perusahaan karena dengan adanya CSR akan menarik perhatian para investor untuk menginvestasikan dananya pada perusahaan tersebut. Sesuai dengan agency theory bahwa ketika terjadi konflik kepentingan antara manajemen dan principal, untuk meminimalisir konflik tersebut perusahaan akan mengeluarkan biaya untuk melakukan kegiatan CSR. Dalam penelitian ini, kinerja keuangan digunakan sebagai variabel pemediasi untuk melihat apakah dengan adanya kinerja keuangan, pengungkapan CSR akan mempengaruhi nilai perusahaan.

Haryanto dan Taufan melakukan penelitian yang berjudul "pengaruh pengungkapan corporate social responsiility terhadap nilai perusahaan dengan kinerja keuangan sebagai variabel intervening" hasil penelitian menunjukkan bahwa: 1. Berdasarkan hasil penelitian diperoleh bahwa CSR berpengaruh signifikan terhadappeningkatan kinerja keuangan perusahaan yang diproksikan dengan ROA dan ROE.Perusahaan yang melakukan pengungkapan CSR yang lebih luas akan memiliki kinerjakeuangan yang lebih baik.2. Berdasarkan hasil penelitian diperoleh bahwa pengungkapan CSR akan meningkatkan nilaiperusahaan3. Berdasarkan hasil penelitian diperoleh bahwa ROE dapat memediasi pengaruh penungkapanCSR terhadap nilai perusahaan. 
Struktur modal terdiri dari komposisi antara penggunaan sumber dana internal dan eksternal yang dikelola oleh suatu perusahaan. Sumber dana internal salah satunya berasal dari setoran modal pemilik. Modal pemilik adalah modal yang dimiliki oleh stockholders, dalam agency theory. Struktur modal disusun untuk mengurangi konflik antar berbagai kelompok kepentingan yaitu stockholders sebagai pihak yang memberi wewenang (principal) dan manajemen sebagai pihak yang diberi wewenang (agen). Berdasarkan penjelasan diatas, struktur modal akan mempengaruhi nilai perusahaan, dan dalam penelitian ini kinerja keuangan digunakan sebagai variabel pemediasi untuk mengetahui apakah struktur modal akan tetap mempengaruhi nilai perusahaan melalui kinerja keuangan.

Artini dkk (2017) melakukan penelitian yang berjudul pengaruh struktur modal terhadap nilai perusahaan dengan profitabilitassebagai variabel intervening pada perusahaan peroperti dan realetate di Bursa Efek Indonesia. Hasil penelitian menunjukkan bahwa profitabilitas mampu memediasi pengaruh struktur modal terhadap nilai perusahaan, karena utang akan dapat meningkatkan nilai perusahaan, dan peningkatan nilai perusahaan ini akan lebih besar apabila utang dapat meningkatkan profitabilitas dari perusahaan.

$\mathrm{H}_{6}$ : CSR berpengaruh positif terhadap nilai perusahaan melalui kinerja keuangan $\mathrm{H}_{7}$ : Struktur modal berpengaruh positif terhadap nilai perusahaan melalui kinerja keuangan.

\section{METODE PENELITIAN}

Penelitian ini menggunakan pendekatan kuantitatif, menurut (Sugiyono, 2013) (Umar, 2003)pendekatan kuantitatif adalah pendekatan dengan pengumpulan data 
menggunakan instrumen penelitian dengan analisis bersifat statistik yang memiliki tujuan menguji hipotesis yang telah ditetapkan serta hubungan variabel terhadap obyek yang diteliti bersifat kausal.Jenis penelitian yang digunakan adalah penelitian eksplanatori (explanatory research) yaitu penelitian yang bertujuan untuk menganalisis hubungan-hubungan antara satu variabel dengan variabel lainnya atau bagaimana suatu variabel mempengaruhi variabel lainnya (Umar, 2003) Penelitian ini dilakukan dengan mengambil data di Bursa Efek Indonesia (BEI) melalui situs web www.idx.co.id.

Populasi yang digunakan dalam penelitian ini adalah perusahaan manufaktur yang terdaftar di Bursa Efek Indonesia (BEI) tahun 2015-2017. Alasan digunakan perusahaan manufaktur adalah dikarenakan perusahaan manufaktur memiliki jumlah perusahaan terbesar. Teknik pengambilan sampel dalam penelitian ini menggunakan metode purposive sampling, yaitu teknik penentuan sampel dengan kriteria tertentu. Kriteria sampel dalam penelitian ini ditunjukkan dalam tabel 1 .

Tabel. 1

\section{Perhitungan Sampel}

\begin{tabular}{|c|c|c|}
\hline No & Kriteria Pemilihan Sampel & Jumlah \\
\hline 1. & $\begin{array}{l}\text { Perusahaan manufakturyang terdaftar di BEI selama berturut-turut dari } \\
\text { tahun } 2015 \text { sampai dengan } 2017 \text {. }\end{array}$ & 144 \\
\hline 2. & $\begin{array}{l}\text { Perusahaan yang tidak mengungkapkan program CSR secara berturut- } \\
\text { turut dan tidak lengkap dalam laporan keuangan tahunan perusahaan } \\
\text { pada tahun } 2015-2017 \text {. }\end{array}$ & $(60)$ \\
\hline 3. & Perusahaan yang memiliki nilai negatif & 33 \\
\hline 4. & $\begin{array}{l}\text { Perusahaan yang tidak terdaftar di Bursa Efek Indonesia sebelum tahun } \\
2015 \text { (IPO pada periode 2015-2017). }\end{array}$ & (13) \\
\hline & Perusahaan yang dijadikan sampel & 38 \\
\hline & Jumlah observasi $(38 \mathrm{X} 3)$ & 114 \\
\hline
\end{tabular}

Sumber: Data diolah, 2018

Variabel independen (terikat) dalam penelitian ini adalah corporate social responsibility dan struktur modal. Variabel bebas dalam penelitian ini yaitu nilai 
perusahaan, variabel intervening adalah variabel yang secara teoritis mempengaruhi hubungan antara variabel independen dengan variabel dependen menjadi hubungan yang tidak langsung dan tidak dapat diamati dan di ukur. Variabel intervening dalam penelitian ini adalah kinerja keuangan.

Alat analisis yang digunakan dalam penelitian ini adalah regresi linier berganda dengan SPSS 23, Sebelum pengolahan data dengan regresi linier berganda terlebih dahulu dilakukan uji asumsi klasik untuk memastikan tidak terjadi normalitas, multikolinearitas, heteroskedastisitas, dan autokorelasi. Apabila uji asumsi klasik sudah terpenuhi, pengujian hipotesis penelitian ini dilakukan dengan menggunakan model analisis jalur. Model persamaan yang digunakan adalah :

$\mathrm{Y}_{1}=\alpha+\mathrm{b}_{1} \mathrm{CSRD}+\mathrm{b}_{2} \mathrm{SM}+€_{1}$

$\mathrm{Y}_{2}=\alpha+\mathrm{b}_{1} \mathrm{CSRD}+\mathrm{b}_{2} \mathrm{SM}_{2}+\mathrm{b}_{3} \mathrm{KN}_{1}+€_{2}$

Keterangan :

$\mathrm{Y}_{1}=$ Kinerja Keuangan

$\mathrm{Y}_{2}=$ Nilai Perusahaan

$\mathrm{CSRD}=$ Pengungkapan CSR

$\mathrm{SM}=$ Struktur Modal

$€_{1,2}=$ Error

\section{HASIL DAN PEMBAHASAN}

Uji normalitas bertujuan untuk menguji apakah dalam model regresi, variabel pengganggu atau resedual memiliki distribusi normal. Dalam penelitian ini normalitas diuji dengan uji Kolmogorov-Smirnov (K-S). Data dikatakan berdistribusi normal jika Asymp. Sig ( 2-tiled) lebih besar dari $\alpha$ 0,05. Hasil uji normalitas ditunjukkan dalam tabel 2. 
Tabel 2.

Hasil Uji Normalitas

\begin{tabular}{|c|c|c|}
\hline & \multicolumn{2}{|c|}{ One Sample Kolmogorof-Smirnov Test } \\
\hline $\begin{array}{l}\mathrm{N} \\
\text { Normal parameters }\end{array}$ & Mean & $\begin{array}{l}\text { Unstandardized Residual } \\
114 \\
, 0000000\end{array}$ \\
\hline & $\begin{array}{l}\text { Std.Deviation } \\
\text { Absolute }\end{array}$ & $\begin{array}{l}, 48161510 \\
, 050\end{array}$ \\
\hline $\begin{array}{l}\text { Test Statistic } \\
\text { Asymp. Sig .(2-tailed) } \\
\begin{aligned} \text { a. } & \text { Test } \\
& \text { distribution is } \\
& \text { Normall }\end{aligned}\end{array}$ & $\begin{array}{l}\text { Positive } \\
\text { Negative }\end{array}$ & $\begin{array}{l}, 050 \\
-, 040 \\
, 050 \\
, 200^{\mathrm{cd}}\end{array}$ \\
\hline
\end{tabular}

Berdasarkan tabel 4.2 di atas, didaatkan nilai Asymp.Sig.(2-tailed) sebesar 0,200. Nilai Asymp.Sig.(2-tailed) 0,200 > 0,05 maka dapat disimpulkan bahwa melalui uji statistik menggunakan uji Kolmogorov-Smirnov terbukti bahwa data residual berdistribusi normal. Model regresi yang baik adalah model regresi yang tidak mengalami multikolinealitas. Multikolonialitas dapat dilihat dari tolerance atau variance inflation factor (VIF). Jika ada nilai tolerance lebih dari 10 persen dan nilai VIF kurang dari 10 persen maka dapat diartikan bahwa tidak ada gejala multikolonialitas. Berikut hasil pengujian multikolonialitas. 
Tabel 3.

Hasil Uji Multikolinearitas

\begin{tabular}{|c|c|c|c|c|c|c|c|}
\hline \multirow[t]{2}{*}{ Model } & \multicolumn{2}{|c|}{$\begin{array}{l}\text { Undstandardized } \\
\text { Coefficients }\end{array}$} & \multicolumn{3}{|c|}{$\begin{array}{l}\text { Standardized } \\
\text { Coefficient }\end{array}$} & \multicolumn{2}{|l|}{$\begin{array}{l}\text { Colinearity } \\
\text { Statistic }\end{array}$} \\
\hline & $\mathrm{B}$ & $\begin{array}{l}\text { Std. } \\
\text { Error }\end{array}$ & Beta & $\mathrm{T}$ & Sig & Tolerance & VIF \\
\hline 1 constanta &,- 165 &, 106 & & $-\overline{1}-556$ & ,123 & & \\
\hline $\begin{array}{l}\text { Corporate } \\
\text { responsibility }\end{array}$ & ,283 & ,089 & ,289 & 3,185 & ,002 & ,966 & 1,036 \\
\hline Ln_SM &,- 194 &, 124 &,- 143 & - & ,119 & ,955 & 1,048 \\
\hline Kinerja Keuangan &, 002 &, 001 & ,219 & 2,445 & ,016 & ,987 & 1,013 \\
\hline
\end{tabular}

a. Dependent

Variabel

LOG_Y

Sumber : Data diolah,2019

Berdasarkan tabel 3 di atas, dari hasil pengujian nilai Tolerance tidak ada yang memiliki nilai kurang dari 0,1 yang berarti tidak ada korelasi antar variabel independen. Hasil perhitungan yang sama di tunjukkan pada nilai VIF, dimana tidak ada variabel independen yang memiliki nilai VIF lebih dari 10, sehingga dapat disimpulkan bahwa data dalam penelitian ini terbebas dari masalah multikolonieritas.

Uji heteroskedastisitas bertujuan menguji apakah dalam model regresi terjadi ketidaksamaan variance dari residual atau pengamatan ke pengamatan yang lain. Jika variance dari residual satu pengamatan ke pengamatan laintetap, maka disebut homoskedastisitas atau tidak terjadi heteroskedastisitas. Dalam penelitian ini untuk mendeteksi gejala heteroskedastisitas digunakan grafik scatterplots, terlihat bahwa titik-titik menyebar secara acak serta tersebar baik diatas mauun di bawah angka 0 pada sumbu $\mathrm{Y}$. 


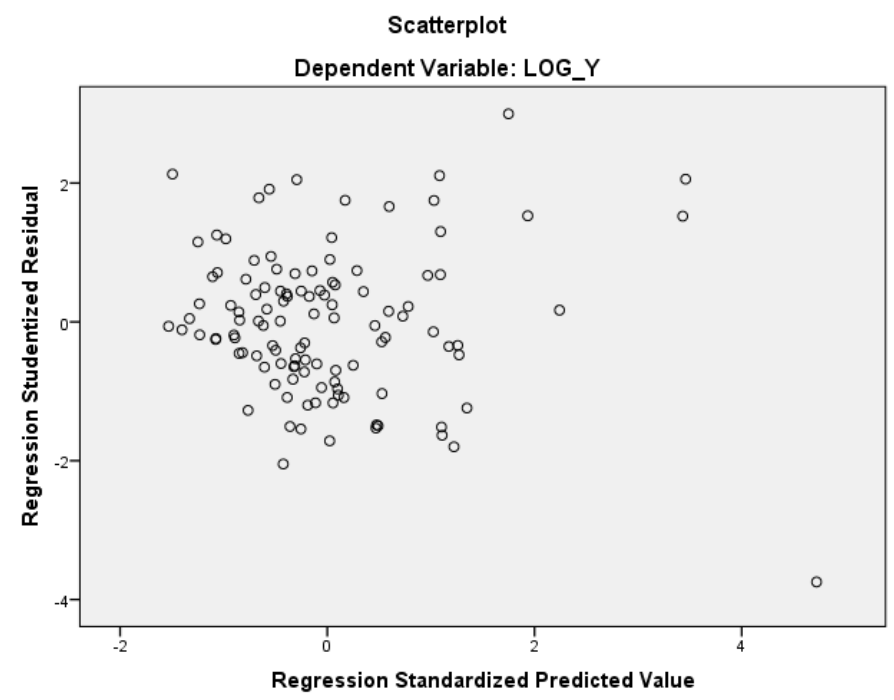

Sumber : Data diolah,2019

Gambar 2. Hasil Uji Hetroskedastisitas

Berdasarkan grafik scatterplot di atas terlihat bahwa titik-titik menyebar secara acak serta tersebar baik di atas maupun di bawah angka 0 pada sumbu Y. Hal ini dapat disimpulkan bahwa tidak terjadi heteroskedastisitas adamodel regresi ini.

Uji autokorelasi bertujuan untuk menguji apakah dalam model regresi linier ada korelasi antara kesalahan pengganggu pada periode t dengan kesalahan pengganggu pada periode t-1 (sebelumnya). Jika terjadi korelasi maka dinamakan ada problem autokorelasi. Berikut adalah tabel hasil uji autokorelasi.

Tabel 4.

Hasil Uji Autokorelasi Model Summary ${ }^{\mathrm{b}}$

\begin{tabular}{lccccr}
\hline Model & $\mathrm{R}$ & R Square & $\begin{array}{c}\text { Adjusted } \mathrm{R} \\
\text { Square }\end{array}$ & $\begin{array}{c}\text { Std. Error of the } \\
\text { Estimate }\end{array}$ & Durbin-Watson \\
\hline 1 &, $358^{\mathrm{a}}$ &, 128 & 104 &, 48814 & 1,069 \\
\hline a. Predictors: (Constant), Kinerja Keuangan, Corporate Social Responsibility, Ln_SM \\
b. Dependent Variable: LOG_Y \\
mber : Data diolah, 2019
\end{tabular}


Hasil uji Durbin-Watson menunjukkan nilai sebesar 1,069. Angka tersebut berada dalam kisaran -2 sampai +2 , sehingga dapat disimpulkan bahwa pengujian tersebut tidak terdapat autokorelasi.

Hasil uji analisis regresi linier berganda dalam penelitian ini dapat dilihat pada tabel 5 .

\section{Tabel 5.}

Uji statistik $\mathbf{t} 1$

\begin{tabular}{|c|c|c|c|c|c|c|}
\hline \multicolumn{7}{|c|}{ Coefficients $^{\mathrm{a}}$} \\
\hline \multirow[b]{2}{*}{ Model } & & \multicolumn{2}{|c|}{$\begin{array}{l}\text { Unstandardized } \\
\text { Coefficients }\end{array}$} & \multirow{2}{*}{$\begin{array}{l}\text { Standardized } \\
\text { Coefficients } \\
\text { Beta }\end{array}$} & \multirow[b]{2}{*}{$\mathrm{T}$} & \multirow[b]{2}{*}{ Sig. } \\
\hline & & $\mathrm{B}$ & Std. Error & & & \\
\hline \multirow[t]{4}{*}{1} & (Constant) &,- 165 & 106 & & $-1,556$ & 123 \\
\hline & $\begin{array}{l}\text { Corporate Social } \\
\text { Responsibility }\end{array}$ & ,283 & ,089 & 289 & 3,185 & ,002 \\
\hline & Ln_SM &,- 194 & ,124 &,- 143 & $-1,571$ & ,119 \\
\hline & Kinerja Keuangan & ,002 & ,001 & ,219 & 2,445 & ,016 \\
\hline
\end{tabular}

a. Dependent Variable: LOG_Y

Sumber : Data diolah, 2019

Berdasarkan tabel 5 di atas persamaan regresi yang dapat dirumuskan

adalah sebagai berikut :

$$
\mathrm{Y} 2=-165+283(\mathrm{X} 1)-194(\mathrm{X} 2)+0,002(\mathrm{Z})+\mathrm{e}
$$

Tabel 6.

Uji Statistik $\mathbf{t} 2$

\begin{tabular}{|c|c|c|c|c|c|c|}
\hline \multirow[b]{3}{*}{ Model } & & \multicolumn{5}{|c|}{ Coefficients $^{\mathrm{a}}$} \\
\hline & & \multicolumn{2}{|c|}{$\begin{array}{l}\text { Unstandardized } \\
\text { Coefficients }\end{array}$} & \multicolumn{3}{|l|}{$\begin{array}{l}\text { Standardized } \\
\text { Coefficients }\end{array}$} \\
\hline & & $\mathrm{B}$ & Std.Error & Beta & $\mathrm{T}$ & Sig. \\
\hline 1 & (Constant) & 30,439 & 11,343 & & 2,683 & ,008 \\
\hline & $\begin{array}{l}\text { CORPORATE SOCIAL } \\
\text { RESPONSIBILITY }\end{array}$ & $-3,550$ & 9,798 &,- 035 &,- 362 & ,718 \\
\hline & Ln_SM & 16,103 & 13,590 &, 114 & 1,185 & ,239 \\
\hline
\end{tabular}

Berdasarkan tabel 4.8 di atas persamaan regresi yang dapat dirumuskan

adalah sebagai berikut :

$$
\mathrm{Y} 1=30,439-3,550(\mathrm{X} 1)+16,103(\mathrm{X} 2)+\mathrm{e}
$$


Berdasarkan hasil uji t pada tabel 5 dan tabel 6 di atas menunjukkan bahwa variabel pengungkapan corporate social responsibility berpengaruh positif terhadap nilai perusahaan. Hasil pengujian menunjukkan bahwa variabel pengungkapan corporate social responsibility memiliki koefisien positif 283 dengan tingkat signifikansi 0,002 lebih kecil dari 0,05 (signifikan). Nilai t hitung variabel pengungkaan corporate scial responsibility adalah 3,185 dan nilai t tabel 2,000. Hasil penelitian ini berarti menolak hipotesis $\mathrm{H}_{0}$ dan menerima $\mathrm{H}_{1}$ atau dengan kata lain hipotesis diterima. Struktur modal berpengaruh negatif terhadap nilai perusahaan. Hasil pengujian menunjukkan bahwa variabel struktur modal yang di ukur dengan DER memiliki koefisien regresi negatif sebesar-194 dengan tingkat signifikansi 0,119 lebih besar dari 0,05 (tidak signifikan). Hasil t hitung adalah -1,571 sedangkan t tabel adalah sebesar 2,000. Hasil tersebut menunjukkan bahwa hipotesis di tolak. Kinerja keuangan berpengaruh positif terhadap nilai perusahaan. Hasil pengujian menunjukkan bahwa variabel kinerja keuangan yang diukur dengan ROE memiliki koefisien positif sebesar 002 dengan tingkat signifikansi 0,016 lebih kecil dari 0,05 (signifikan). Nilai t hitung 2,445 lebih besar dari t tabel 2,000. Hal tersebut menunjukkan bahwa ROE berpengaruh signifikan terhadap nilai perusahaan atau dengan kata lain $\mathrm{H}_{3}$ diterima.bahwa struktur modal berengaruh positif terhadap kinerja keuangan. Hasil pengujian menunjukkan bahwa struktur modal yang diukur dengan menggunakan DER memiliki koefisien 16,103 dengan signifikansi 0,239 lebih besar dari 0,05 (tidak signifikan). Sedangkan hasil uji parsial t hitung $(1,185)$ lebih kecil dari t tabel (2,000). Hasil tersebut menunjukkan bahwa struktur modal tidak berpengaruh 
positif terhadap kinerja keuangan dengan katalain hipotesis di tolak. Kinerja keuangan berpengaruh positif terhadap nilai perusahaan. Hasil pengujian menunjukkan bahwa variabel kinerja keuangan yang diukur dengan ROE memiliki koefisien regresi sebesar 0,002 dengan tingkat signifikansi sebesar 0,016 lebih kecil dari 0,05 (signifikan). Sedangkan nilai t hitung $(2,445)$ lebih besar dari nilai $\mathrm{t}$ tabel $(2,000)$. Hal tersebut menunjukkan bahwa kinerja keuangan berpengaruh positif terhadap nilai perusahaan.

Analisis jalur ialah suatu teknik untuk menganalisis hubungan sebab akibat yangterjadi pada regresi berganda jika variabel bebasnya mempengaruhi variabel tergantungtidakhanya secara langsung, tetapi juga secara tidak langsung. Berikut adalah hasil uji analisis jalur.

Tabel 7. Hasil Uji Koefisien Determinasi (1)

\begin{tabular}{ccccc}
\hline Model & $\mathrm{R}$ & $\mathrm{R}$ Square & Adjusted R Square & $\begin{array}{c}\text { Std. Error } \\
\text { of the } \\
\text { Estimate }\end{array}$ \\
\hline 1 &, 014 &, 000 &,- 009 & 54,05633 \\
\hline a. Predictors: (Constant), CORPORATE SOCIAL RESPONSIBILITY \\
Sumber: Data diolah, 2019
\end{tabular}

Hasil pengujian pada tabel 7 di atas menunjukkan bahwa nilai $\mathrm{R}^{2}$ sebesar $0,009 \%$. Angka ini menunjukkan bahwa sebesar $9 \%$ nilai perusahaan dipengaruhi oleh corporate social responsibility.

Tabel 8.

Hasil Uji Statistik F (1)

\begin{tabular}{lllllll}
\hline Model & $\begin{array}{l}\text { Sum of } \\
\text { Squares }\end{array}$ & Df & $\begin{array}{l}\text { Mean } \\
\text { Aquare }\end{array}$ & F & Sig. \\
& Regression & 64,136 & 1 & 64,136 &, 022 &, $882^{\mathrm{b}}$ \\
$\quad$ Residual & 327273,721 & 112 & 2922,087 & & \\
$\quad$ Total & 327337,856 & & & & &
\end{tabular}


ISSN: 2302-8556

E-Jurnal Akuntansi Universitas Udayana Vol.27.1.April (2019): 764-791

Hasil uji F pada tabel 8 di atas menunjukkan bahwa nilai f hitung sebesar 0,022 dengan probabilitas 0,882 .

Tabel 9.

Hasil Uji Statistik t (1)

Unstandardized

Coefficients

Standardized Sig.

Coefficients

Sig.

$\mathrm{T}$

\begin{tabular}{lllllll} 
Model & & \multicolumn{5}{c}{ S } \\
\cline { 3 - 6 } & B & Std.Error & Beta & & \\
\hline 1 & (Constant) & 25,370 & 10,525 & & 2,411 &, 018 \\
& Corporate Social & $-1,430$ & 9,651 &,- 014 &,- 148 &, 882 \\
& Responsibility & & & & &
\end{tabular}

a. Dependent Variable : KINERJA KEUANGAN

Sumber : Data, diolah 2019

Tabel 9 di atas menunjukkan bahwa hasil uji statistik t untuk variabel corporate social responsibility adalah sebesar -0,148 dan siignifikansi pada 0,882.

Artinya bahwa corporate social responsibility tidak berpengaruh terhadap kinerja keuangan.

Tabel 10.

Hasil Uji Statistik Koefisien Determinasi (2)

\begin{tabular}{ccccc}
\hline Model & $\mathrm{R}$ & $\mathrm{R}$ Square & $\begin{array}{c}\text { Adjusted R } \\
\text { Square }\end{array}$ & $\begin{array}{c}\text { Std. Error of the } \\
\text { Estimate }\end{array}$ \\
\hline 1 &, $330^{\mathrm{a}}$ &, 109 &, 093 &, 49135 \\
\hline
\end{tabular}

Sumber: Data diolah, 2019

Berdasarkan tabel di atas menunjukkan bahwa pada persamaan kedua terdapat adjusted $\mathrm{R}$ square sebesar 0,093 atau 9,3\%. Hal ini menunjukkan bahwa 9,3\% variabel nilai perusahaan dipengaruhi oleh kinerja keuangan dan corporate social responsibility sedangkan sisanya dipengaruhi oleh variabel lain yang tidak digunakan dalam penelitian ini. 
Tabel 11.

Hasil Uji Statistik F (2)

\begin{tabular}{llrrrrr}
\hline Model & & \multicolumn{1}{c}{ Sum of } & & & & \\
\hline 1 & Squares & Df & Mean Square & F & \multicolumn{1}{c}{ Sig. } \\
\hline & Residual & 3,266 & 2 & 1,633 & 6,763 &, $002^{\mathrm{b}}$ \\
& Total & 26,799 & 111 &, 241 & & \\
\hline
\end{tabular}

a. Dependent Variable: LOG_Y

b. Predictors: (Constant), Kinerja Keuangan, Corporate Social Responsibility

Sumber: Data diolah, 2019

Hasil uji f seperti ditunjunjukkan di atas dalam tabel 11 menunjukkan bahwa $\mathrm{F}$ hitung sebesar 6,763 dengan nilai signifikansi 0,002 di bawah 0,05 maka dapat disimpulkan bahwa variabel kinerja keuangan dan corporate social responsibility secara bersama-samaberpengaruh terhadap nilai perusahaan.

Tabel 12.

Hasil Uji Statistik t (2)

\begin{tabular}{|c|c|c|c|c|c|c|}
\hline \multirow[b]{2}{*}{ Model } & & \multicolumn{2}{|c|}{$\begin{array}{c}\text { Unstandardized } \\
\text { Coefficients }\end{array}$} & $\begin{array}{c}\text { Standardi } \\
\text { zed } \\
\text { Coefficie } \\
\text { nts } \\
\end{array}$ & \multirow[b]{2}{*}{$\mathrm{T}$} & \multirow[b]{2}{*}{ Sig. } \\
\hline & & B & $\begin{array}{l}\text { Std. } \\
\text { Error }\end{array}$ & Beta & & \\
\hline 1 & (Constant) &,- 100 & ,098 & & $-1,017$ & ,311 \\
\hline & $\begin{array}{l}\text { Corporate Social } \\
\text { Responsibility }\end{array}$ & ,257 & ,088 & ,262 & 2,926 & ,004 \\
\hline & $\begin{array}{l}\text { Kinerja } \\
\text { Keuangan }\end{array}$ & ,002 & ,001 & ,203 & 2,269 & ,025 \\
\hline
\end{tabular}

a. Dependent Variable: LOG_Y

Sumber: Data diolah, 2019

Hasil uji statistik t di atas untuk variabel corporate social responsibility adalah sebesar 2,926 dan signifikansi 0,004 artinya bahwa corporate social responsibility berpengaruh terhadap nilai perusahaan. Sedangkan untuk kinerja keuangan uji statistik t menunjukkan sebesar 2,296 dan signifikansi 0,025 artinya bahwa struktur modal berpengaruh terhadap nilai perusahaan. 
Berdasarkan hasil output spss di atas nilai standardized beta pada persamaan pertama adalah $-0,014$ dan tidak signifikan pada 0,882 yang berarti CSR tidak mempengaruhi nilai perusahaan. Nilai koefisien standardzed beta 0,014 merupakan nilai path ataujalur p2. Pada output SPSS persamaan regresi (2) nilai standardzed untuk corporate social responsibility adalah 0,262 dan kinerja keuangan 0,203 semuanya signifikan. Nilai standardized beta corporate social responsibility 0,262 merupakan nilai jalur p1 dan nilai standardized beta kinerja keuangan 0,203 merupakan nilai jalur p3. Besarnya nilai e1 $=\sqrt{1-0,000}=$ 1 dan besarnya nilai e $2==\sqrt{(1-0,109)}=0,943$.

Hasil analisis jalur menunjukkan bahwa corporate sosial responsibility dapat berpengaruh langsung ke nilai perusahaan dan dapat juga tidak berpengaruh langsung yaitu dari corporate social responsibility ke kinerja keuangan (sebagai intervening) lalu ke nilai perusahaan. Besarnya pengaruh lanngsung adalah 0,262 sedangkan besarnya pengaruh tidak langsung harus dihitung dengan mengalikan koefisien tidak langsungnya yaitu $(-, 014) \times(0,203)=-0,0039$, atau total pengaruh corporate social responsibility ke nilai perusahaan $=0,262+-0,0039=0,2581$. Perbandingan pengaruh pengaruh tidak langsung CSR terhadap nilai perusahaan melalui kinerja keuangan (ROE) dengan pengaruh langsung CSR terhadap nilai perusahaan di dapatkan hasil $-0,0039<0,2581$, sehingga bias dinyatakan bahwa kinerja keuangan (ROE) tidak dapat berfungsi sebagai variabel intervening dalam pengaruh CSR terhadap nilai perusahaan pada perusahaan manufaktur di BEI periode 2015-2017. 
Hipotesis keenam menyatakan bahwa kinerja keuangan mampu memediasi hubungan antara struktur modal terhadap nilai perusahaan.Hasil uji analisis jalur untuk hipotesis keenam dapat di lihat pada tabel 13.

Tabel 13.

Hasil Uji Koefisien Determinasi

\begin{tabular}{lrrrr}
\hline Model & R & R Square & $\begin{array}{c}\text { Adjusted R } \\
\text { Square }\end{array}$ & $\begin{array}{c}\text { Std. Error of the } \\
\text { Estimate }\end{array}$ \\
\hline 1 &, $107^{\text {a }}$ &, 012 &, 003 & 53,74939 \\
\hline a. Predictors: (Constant), Ln_SM & & &
\end{tabular}

Sumber: Data diolah, 2019

Berdasarkan tabel 13 di atas diperoleh nilai koefisien determinasi sebesar 0,003. Hal ini menunjukkan bahwa 0,003 variabel struktur modal dipengaruhioleh kinerja keuangan.

Tabel 14.

Hasil uji statistik F

\begin{tabular}{|c|c|c|c|c|c|c|}
\hline Model & & $\begin{array}{l}\text { Sum of } \\
\text { Squares }\end{array}$ & Df & Mean Square & $\mathrm{F}$ & Sig. \\
\hline \multirow[t]{3}{*}{1} & Regression & 3770,149 & 1 & 3770,149 & 1,305 & $256^{\mathrm{b}}$ \\
\hline & Residual & 323567,707 & 112 & 2888,997 & & \\
\hline & Total & 327337,856 & 113 & & & \\
\hline
\end{tabular}

a. Dependent Variable: KINERJA KEUANGAN

b. Predictors: (Constant), Ln_SM

Sumber: Data diolah, 2019

Berdasarkan hasil uji f pada tabel 14 di atas diperoleh $\mathrm{f}$ hitung sebesar 1,305 dan signifikansi sebesar 0,256.

Tabel 15. Hasil Uji Statistik t

\begin{tabular}{|c|c|c|c|c|c|c|}
\hline \multirow[b]{2}{*}{ Model } & & \multicolumn{2}{|c|}{ Unstandardized Coefficients } & $\begin{array}{l}\text { Standardized } \\
\text { Coefficients }\end{array}$ & \multirow[b]{2}{*}{$\mathrm{T}$} & \multirow[b]{2}{*}{ Sig. } \\
\hline & & $\mathrm{B}$ & Std. Error & Beta & & \\
\hline 1 & (Constant) & 26,875 & 5,627 & & 4,776 &, 000 \\
\hline & Ln_SM & 15,204 & 13,309 & , 107 & 1,142 & ,256 \\
\hline
\end{tabular}

a. Dependent Variable: KINERJA KEUANGAN

Sumber : Data diolah, 2019 
Berdasarkan hasil uji $\mathrm{t}$ seperti ditunjukkan di atas pada tabel 15 menunjukkan nilai t untuk variabel struktur modal adalah sebesar 1,142 dan signifikansi sebesar 0,256.

Tabel 16.

Hasil Uji Koefisien Determinasi

\begin{tabular}{lcccc}
\hline Model & R & R Square & $\begin{array}{c}\text { Adjusted R } \\
\text { Square }\end{array}$ & $\begin{array}{c}\text { Std. Error of the } \\
\text { Estimate }\end{array}$ \\
\hline 1 &, $187^{\text {a }}$ &, 035 &, 018 & 8,91555 \\
\hline a. Predictors: (Constant), KINERJA KEUANGAN, Ln_SM &
\end{tabular}

Sumber: Data diolah, 2019

Berdasarkan tabel 16 di atas diperoleh nilai adjusted $\mathrm{r}$ square adalah sebesar 0,018 atau $18 \%$ artinya bahwa sebesar $18 \%$ nilai perusahaan dipengaruhi oleh kinerja keuangan dan struktur modal.

Tabel 17.

Hasil Uji Statistik F

\begin{tabular}{llrrrrr}
\hline Model & & Sum of Squares & Df & Mean Square & F & \multicolumn{1}{c}{ Sig. } \\
\hline 1 & Regression & 321,417 & 2 & 160,709 & 2,022 &, $137^{\text {b }}$ \\
& Residual & 8823,052 & 111 & 79,487 & & \\
& Total & 9144,470 & 113 & & & \\
\end{tabular}

a. Dependent Variable: NILAI PERUSAHAAN

b. Predictors: (Constant), KINERJA KEUANGAN, Ln_SM

Sumber: Data diolah, 2019

Berdasarkan tabel 17 di atas diperoleh bahwa hasil untuk uji f hitung adalah sebesar 2,022 dan signifikansi pada 0,137. Artinya bahwa tidak ada pengaruh antar variabelkinerja keuangan dan struktur modal terhadap nilai perusahaan.

Tabel 18. Hasil Uji Statistik t

\begin{tabular}{|c|c|c|c|c|c|c|}
\hline \multirow{2}{*}{\multicolumn{2}{|c|}{ Model }} & \multicolumn{2}{|c|}{$\begin{array}{l}\text { Unstandardized } \\
\text { Coefficients }\end{array}$} & \multirow{2}{*}{$\begin{array}{l}\text { Standardized } \\
\text { Coefficients } \\
\text { Beta }\end{array}$} & \multirow[b]{2}{*}{$\mathrm{T}$} & \multirow[b]{2}{*}{ Sig. } \\
\hline & & $\mathrm{B}$ & Std. Error & & & \\
\hline \multirow[t]{3}{*}{1} & (Constant) & 3,635 & 1,024 & & 3,549 &, 001 \\
\hline & Ln_SM & 1,931 & 2,220 & ,082 & ,869 & ,386 \\
\hline & Kinerja Keuangan &, 027 & ,016 & 160 & 1,709 & 090 \\
\hline
\end{tabular}

a. Dependent Variable: Nilai Perusahaan Sumber: Data diolah, 2019 
Berdasarkan tabel 18 di atas menunjukkan hasil uji statistik t untuk variabel struktur modal adalah sebesar 0,869 dan signifikansi sebesar 0,386. Sedangkan untuk variabel kinerja keuangan uji statistik diperoleh angka sebesar 1,709 dengan signifikansi sebesar 0,090.

Berdasarkan hasil output spss di atas nilai standardized beta pada persamaan pertama adalah 0,107 dan signifikansi pada 0,256 yang berarti struktur modal tidak mempengaruhi nilai perusahaan. Nilai koefisien standardized beta 0,107 merupakan nilai path atau jalur 2. Pada output spss persamaan regresi (2) nilai standardized beta struktur modal adalah 0,082 dan kinerja keuangan adalah 0,160 dan tidak signifikan. Nilai standardized beta struktur modal 0,082 merupakan nilai jalur path p1 dan nilai standardized beta kinerja keuangan 0,160 merupakan nilai jalur path p3. Besarnya nilai e1 $==\sqrt{(1-0,012)}=0,994$ dan nilai e2 $=\sqrt{(1-0,035)}=0,982$.

Hasil analisis jalur menunjukkan bahwa struktur modal dapat berpengaruh langsung ke nilai perusahaan dan dapat juga berpengaruh tidak langsung yaitu dari struktur modal ke kinerja keuangan (sebagai intervening) lalu ke nilai perusahaan. Besarnya pengaruh langsung adalah 0,082 sedangkan besarnya pengaruh tidak langsung adalah $=(0,107) X(0,160)=0,0171$ dan total pengaruh langsung dari struktur modal ke nilai perusahaan adalah $0,082+(0,0171)=$ 0,0014. Penelitian ini menemukan bahwa pengaruh tidak langsung struktur modal terhadap nilai perusahaan melalui kinerja keuangan yang diproksikan dengan ROE yaitu sebesar 0,0171 lebih besar pengaruhnya daripada pengaruh langsung struktur modal terhadap nilai perusahaan yaitu sebesar 0,0014 , sehingga dapat 
dikatakan bahwa kinerja keuangan yang diproksikan dengan ROE dalam penelitian ini dapat berfungsi sebagai variabel intervening.

Penelitian ini konsisten dengan penelitian yang dilakukan oleh (Hamidy, Wiksuana, Gede, \& Artini, 2015) yang menyatakan bahwa perusahaan dapat meningkatkan nilai perusahaannya dengan meningkatkan utang, dimana peningkatan utang tersebut dapat meningkatkan kinerja keuangan (ROE).Peningkatan utang seperti yang telah dijelaskan sebelumnya, pada keadaanmanfaat yang ditimbulkan dari utang lebih besar dari pengorbanan yangditanggung perusahaan dari utang yang diterbitkan, atau dengan kata lainpengurangan pajak dan pengurangan biaya agensi lebih besar dampaknya daripadabunga yang ditimbulkan oleh utang tersebut, maka peningkatan utang akanmeningkatkan pendapatan bersih dari perusahaan yang berujung pada naiknyanilai ROE. ROE yang tinggi akan menjadi penanda yang baik bagi pemegangsaham atau calon pemegang saham, sebab ROE sebagai rasio dari pengembalianatas dana yang ditanamkan oleh pemegang saham. Ketertarikan pemegang sahamdan calon pemegang saham akanmeningkatkan permintaan terhadap saham dariperusahaan sehingga harga saham akanmengalami kenaikkan atas hal tersebut,kenaikkan harga saham mendorong nilai perusahaan untuk naik. KeberadaanROE yang menjadi intervening hubungan antara struktur modal dengan nilaiperusahaan menunjukkan hasil yang lebih tinggi daripada pengaruh langsungstruktur modal pada nilai perusahaan tanpa intervening kinerja keuangan (ROE). 


\section{SIMPULAN}

Hasil penelitian ini juga sejalan dengan (Hamidy et al., 2015) yang menyatakan bahwa struktur modal berpengaruh terhadap nilai perusahaan dengan kinerja keuangan sebagai variabel intervening. Perusahaan dapat meningkatkan nilai perusahaannya dengan meningkatkan utang, dimana peningkatan utang tersebut dapat meningkatkan kinerja keuangan (ROE).Peningkatan utang seperti yang telah dijelaskan sebelumnya, pada keadaanmanfaat yang ditimbulkan dari utang lebih besar dari pengorbanan yangditanggung perusahaan dari utang yang diterbitkan, atau dengan kata lainpengurangan pajak dan pengurangan biaya agensi lebih besar dampaknya daripadabunga yang ditimbulkan oleh utang tersebut, maka peningkatan utang akanmeningkatkan pendapatan bersih dari perusahaan yang berujung pada naiknyanilai ROE.

Beberapa keterbatasan dan saran dalam penelitian ini, yang dapat memberikan arah pada peneliti selanjutnya sebagai berikut :

Hasil penelitian menunjukkan bahwa variabel nilai perusahaan dan kinerja keuangan hanya mampu menjelaskan variabel pengungkapan csr sebesar 10,4\% dan sisanya dipengaruhi oleh variabel lainnya (lemah).saran bagipeneliti selanjutnya adalah untuk menguji kembali dan menambahkan variabel independen lainnya yang mungkin akan berpengaruh terhadap pengungkapan CSR dan struktur modal.

Pada penelitian ini hanya menggunakan perusahaan manufaktur yang melaporkan CSR. Saran untuk peneliti selanjutnya yaitu dengan memperluas 
perusahaan seperti seluruh perusahaan yang terdaftar di bursa efek Indonesia. Dan untuk tahun penelitian sebaiknya menggunakan tahun terbaru dan diperbanyak.

\section{REFERENSI}

Edison. (2013). Pengaruh Struktur Modal terhadap Nilai Perusahaan dengan Kinerja Keuangan sebagai Variabel Intervening pada Perusahaan LQ-45 di Bursa Efek Indoensia.

Fahmi, I. (2016). Pengantar Manajemen Keuangan. Bandung: Alfabeta.

Hafsah, \& Sari, S. S. S. (2015). Analisis Struktur Modal terhadap Kinerja Keuangan Pada Perusahaan Properti dan Real Estate yang terdaftar di BEI. Jurnal Riset Akuntansi Dan Bisnis, 15(1), 52-64

Hamidy, R. R., Wiksuana, I. G. B., Gede, L., \& Artini, S. (2015). Dengan Profitabilitas Sebagai Variabel Intervening Pada Perusahaan Properti Dan Real Estate Di Bursa Efek Indonesia Fakultas Ekonomi dan Bisnis Universitas Udayana ( Unud ), Bali , Indonesia Email : rahmanhamidy@gmail.com Tren investasi yang berkembang di. Jurnal Manajemen Unud, 10, 665-682.

Jensen, M. C., \& Meckling, W. H. (1976). Theory of the Firm : Managerial Behavior, Agency Costs and Ownership Structure. Journal of Financial Economics, 3, 305-360.

Maryanto, H. K. (2017). Pengaruh Intellectual Capital dan Good Corporate Governance trhadap nilai perusahaan dengan kinerja keuangan sebagai variabel intervening pada perusahaan manufaktur di Bursa Efek Indonesia Tahun 2011-2014. JOM Fekon, 4(1), 1598-1612.

Moniaga, F. (2013). Struktur Modal, Profitabilitas dan Struktur Biaya terhadap Nilai Perusahaan Industri Keramik, Porcelen dan Kaca Periode 2007-2011. Jurnal EMBA, 1(4), 433-442.

Nadillah, D. Y. (2017). Pengaruh Struktur Modal dan Pertumbuhan Perusahaan terhadap nilai perusahaan yang dimediasi kinerja keuangan dengan pengungkapan corporate social responsibility sebagai variabel pemoderasi pada perusahaan manufaktur di Bursa Efek Indonesia Th. 2011-2014. JOM Fekon, 4(1), 601-615.

Pratheepkanth, P. (2011). Capital Structure and financial performance : Evidence from selected business companies in colombo stock exchange Sri Lanka. Jornal of Arts, Science \& Commerce, II(2), 171-183. 
Ramadhani, A. R., Purnamawati, I. G. A., \& Sujana, E. (2017). Pengaruh corporate social responsibility dan kepemilikan manajerial terhadap nilai perusahaan dengan profitabilitas sebagai variabel moderating. S1 Ak Universitas Pendidikan Ganesha, 7(1).

Retno, R. D., \& Priantinah, D. (2012). Pengaruh Good Corporate Governance dan Pengungkapan Corporate Social Responsibility terhadap Nilai Perusahaan (Studi Empiris Pada Perusahaan yang terdaftar di Bursa Efek Indonesia Periode 2007-2010). Jurnal Nominal, I.

Sari, N. L. K. M., \& Suaryana, I. G. N. A. (2013). Pengaruh Pengungkapan CSR terhadap Kinerja Keuangan dengan kepemilikan asing sebagai variabel moderator. Jurnal Akuntansi Universitas Udayana, 248-257.

Sugiyono. (2013). Metode Penelitian Kombinasi.Cetakan Keempat. Bandung: Alfabeta.

Umar, H. (2003). Metode Penelitian Kombinasi.Cetakan Keempat. Jakarta: Gramedia Pustaka Utama. 